\title{
Equilibrium
}

Quarterly Journal of Economics and Economic Policy

VOLUME 9 ISSUE 1, 2014

p-ISSN 1689-765X, e-ISSN 2353-3293

www.economic-policy.pl

Grodzicki M. (2014), Structural Similarities of the Economies of the European Union, "Equilibrium. Quarterly Journal of Economics and Economic Policy", Volume 9, Issue 1, pp. 93-117, DOI: http://dx.doi.org/10.12775/EQUIL.2014.006

\section{Structural Similarities of the Economies of the European Union**}

JEL Classification: $E 23, F 15, O 14$

Keywords: economic structure, structural convergence, European integration

\begin{abstract}
From the point of view of the consequences of European integration, similarities of economic structures of member states are of high relevance. The main objective of the paper is to analyse how those similarities looked like in the period of 1970-2006 for EU15 and in 1995-2006 for EU25 countries. The analysis consists of two stages and refers to the similarities in employment composition between three sectors of economy, and also between subsectors of manufacturing and services - distinguished on the basis of their technological advancement and knowledge intensity. In the first step, on the basis of the EU-KLEMS database, a measure of structural similarity, Krugman specialization index, was calculated for all pairs of EU countries. Observation of its values points to an ongoing homogenization of EU15 economies and of their manufacturing structures, but also to an increase in differences of knowledge intensity in services. In the broader sample of EU25, despite an ongoing economic transition, no significant homogenization of structures was observable. As the second step, a cluster analysis was conducted, which allowed for identification of development patterns in the sample of European countries.
\end{abstract}

\footnotetext{
(C) Copyright Institute of Economic Research \& Polish Economic Society Branch in Torun Date of submission: April 2, 2013; date of acceptance: September 17, 2013

* Contact: maciej.grodzicki@uj.edu.pl, ul. prof. S. Łojasiewicza 4, 30-348 Kraków, Poland

${ }^{* *}$ The paper was prepared within the research project "Convergence in countries and regions of the European Union" funded by the Polish National Science Centre, on the basis of the decision No. DEC-2011/01/N/HS4/03077.
} 


\section{Introduction}

The main objective of the article is to investigate the level and the dynamics of structural similarities between economies of member states of the European Union. Economic structure is understood, following S. Kuznets (1949, p. 205), as "the relative distribution of its [economy's] resources and total output among the several industries". We analyse distribution of employment between the main economic sectors and between manufacturing and services subsectors. The analysis is conducted for two samples: for the old member countries (EU15) in 1970-2006 and for the enlarged European Union (EU25) in 1995-2006.

The problem seems to be worth investigating for a number of reasons. First and foremost, economic development and catching-up processes are strictly interrelated with structural changes, while economic structure is one of the major factors of growth potential of a country (Cornwall, Cornwall 1994; Kuznets 1987). Hence, structural similarities between European economies may influence the conditions for a cohesive development of the European Union. Secondly, theoretical predictions regarding the relationship between structural change and economic growth are ambiguous (e.g. ECB 2004): economic processes can lead either to a narrowing or to a widening of structural differences between countries, depending on the theoretical assumptions.

Previous empirical research demonstrates that EU member states became more and more homogenous in terms of economic structure - at a high level of aggregation. However, little research has been conducted regarding the new member states. Therefore, the primary objective of the research is to analyse the structural similarities between EU15 and EU25 countries on the basis of possibly most up-to-date data. The secondary objective is to provide insights for further analyses conducted within the project "Convergence in the countries and regions of the European Union".

In the second section of the paper, the most important theoretical insights about the evolution of economic structure are presented. A review of empirical analysis regarding European countries is provided as well. Altogether, it enables us to present research hypotheses and develop statistical techniques, which are described in details in section three. Sections four and five contain presentation of results, while section six concludes and indicates directions for further research. 


\section{Economic structure in theory and empirics}

The evolution of economic structure and its relationship with economic development used to be one of the major research area of economists in the post-war period. Since economic sectors are characterized by different specificity of products, production and innovation processes, but also of working and living conditions of engaged persons, it became necessary to include this specificity in the research program of development economics (Kuznets 1949).

Contemporary analyses of the relationships between economic structure and development are heavily influenced by J. Schumpeter's legacy (1942). In his vision, economic development actually consists of continuous transformation of economic structure and is driven by new sectors, which however, over time tend to lose much of its initial dynamics. From the point of view of our analysis, important insights can be found in the writings of $\mathrm{C}$. Clark (1951), who distinguished three sectors - agriculture, manufacturing and services - as three qualitatively different areas of economic activity. Along the development path and with the enrichment of the society, the shares of those three sectors in employment of production factors and in produced output are changing. The common pattern in economic history was the one of shifting the economic resources from agriculture to manufacturing (the industrialization phase), and then to services (the deindustrialization or tertiarisation phase). Clark attributed this phenomena predominantly to changes in demand patterns, caused by increasing income levels and living standards of the society.

However, such shifts in structure require also developments on the supply side of the economy - it has to be able to provide a certain amount of aggregate product, to accumulate enough physical capital and to develop new types of activities (Rosenstein-Rodan 1944). According to W. Baumol (in: Schettkat, Yokarini 2003), structural dynamics is a derivative of changes in relative productivities of particular sectors - those with rapidly growing productivity produce more, with constant or even diminishing labour outlays and with decreasing relative prices. A combination of both described ideas can be found, for instance, in the theory of stages of economic growth of W. Rostow (1959). Growth should be analysed in terms of a sequence of following dominant economic sectors. It is the technological dynamics and strategic decisions of whole society (in many areas, e.g. development priorities, redistribution, fertility) that determine which sector is currently leading. 
From the point of view of our analysis, the most important conclusion from structural theories is the one that states that economies while developing undergo common patterns of structural dynamics (Chenery, Watanabe 1958; Chenery 1982; Kenessey 1987; Döhrn, Heilemann 1996; Rowthorn, Ramaswamy 1997). If this regularity was to hold nowadays, we could expect that economic convergence of European countries would be accompanied by homogenization of their economic structures. Chenery and Taylor (1968) conducted probably the first quantitative comparison of development patterns on a big sample of countries and demonstrated that shares of particular sectors were very similar within three subsamples: large countries, small traditional countries and small industrial countries.

Analyses of structural change in the European Union indicate that in recent years deindustrialization was a common phenomenon. It was caused by both: changes in demand structure and productivity growth in manufacturing. Although manufacturing production has been steadily increasing in recent years, the employment share of secondary sector has been declining (Debande 2009). What is more, European economies have been steadily converging to each other in structural terms - since the 1970's structural homogeneity on the level of large economic sectors has been steadily increasing. We can expect to observe similar, small structural differences, due to the fact that all European countries are on a high level of development.

Several authors point out the importance of structural change for a successful integration of the Central and Eastern Europe countries with the European Union (Landesmann 2000; Stephan 2002). Empirical analyses from the pre-accession period demonstrate that the CEE countries, although all were different from the EU15 economies, varied a lot in terms of their economic structures. Most of the countries of this region used to have in the 90's an overdeveloped industrial sector and underdeveloped services sector (Döhrn, Heilemann 1996; Mickiewicz, Zalewska 2005). According to Stephan (2002), the need for structural change was the most emphasized in Hungary, Slovakia, Slovenia, while Estonia and the Czech Republic had beneficial structures of employment. Poland was a separate case, with an exceptionally high share of employment in agriculture. However, a more detailed approach, presented by Landesmann (2000), indicates that the structure of manufacturing of the Czech Republic, Slovakia and Slovenia resembled the one of Northern Europe economies, whereas the one of Poland was similar to Southern Europe countries.

On a lower level of aggregation, an undergoing specialization in the European Union has been observed (Marelli 2004; Höhenberger, Schmiedeberg 2008). Therefore, the second, more detailed dimension of analyses of economic structures can refer to technological advancement of economic activity within particular sectors. We pose the question that potentially will lead us 
to some interesting results: are sectors of manufacturing and services of European countries homogenous in terms of their internal structure? It might turn out that the countries similar to each other at the level of the whole economy are characterized by totally different distributions of employment when more detailed analysis is conducted.

This particular problem is investigated by the literature of intrasectoral specialization (e.g. ECB 2004; Höhenberger, Schmiedeberg 2008). In this paper, I would like to propose a slightly different approach that might lead us to conclusions of a different nature. We can observe that both manufacturing and services industries are characterized by different levels of technological advancement and of general sophistication of economic activity. In manufacturing we can distinguish both traditional, labour-intensive industries and modern industries, with higher capital intensity or making use of high technologies. In the services, such distinction will rather be made on the basis of skills and education level of employees.

Along the development path, we can expect that employment shifts will take place not only between sectors, but also within them. Enrichment of society and enhancement of its capabilities enable it to adopt and produce frontier technologies and to undertake more sophisticated activities, which demand high qualifications of employees. On the other hand, development of such industries should contribute positively to productivity dynamics in the whole economy. However, such beneficial structural change is in no way automatic - economic structures are characterised by strong path dependence and development of new industries requires a certain level of widely understood capabilities - on the level of both individual company and whole society (Perez 1983; Malerba 2002).

Having all of this in mind, the second objective of the research will be to analyse similarities of economic structures of European economies on a less aggregated, intrasectoral level. Here, we will make use of Eurostat (2011) classifications of manufacturing subsectors (according to their technological advancement) and services subsectors (according to their knowledge intensity).

\section{Research methods}

The analysis of structural similarities will be conducted in two stages. Firstly, we will investigate statistical measures chosen to describe the level of similarities of economic structures - distinguished in three ways: for the whole economy, manufacturing and services. 
Division of the economy in three sectors (in Table 1) will be made according to Clark's classification and Rostow's theory of phases of development.

Table 1. Division of economic activities into three sectors

\begin{tabular}{|l|l|c|}
\hline \multicolumn{1}{|c|}{ Sector } & \multicolumn{1}{|c|}{ Includes subsectors: } & $\begin{array}{c}\text { ISIC-3 } \\
\text { Code }\end{array}$ \\
\hline Primary & Agriculture, Hunting, Forestry and Fishing & A-B \\
(S1) & Mining and Quarrying & C \\
\hline Secondary & Total Manufacturing & D \\
(S2) & Electricity, Gas and Water Supply & E \\
& Construction & F \\
\hline Tertiary & Wholesale and Retail Trade & G \\
(S3) & Hotels and Restaurants & H \\
& Transport and Storage and Communication & I \\
& Finance, Insurance, Real Estate and Business Services & J-K \\
& Community Social and Personal Services & L-Q \\
\hline
\end{tabular}

Source: own preparation on the basis of EU-KLEMS data.

The division of manufacturing and services subsectors into categories will be conducted on the basis of sectoral taxonomy of Eurostat (2011), according to their global technological intensity (in manufacturing, Table 2) and their knowledge-intensity (in services, Table 3). Due to the limited availability of employment data at sectoral level, the division had to be slightly adopted for research purposes, and therefore does not reflect the Eurostat classification perfectly.

Table 2. Division of manufacturing industries on the basis of technological advancement

\begin{tabular}{|l|l|l|}
\hline $\begin{array}{c}\text { Technological } \\
\text { advancement }\end{array}$ & \multicolumn{1}{|c|}{ Includes subsectors: } & \multicolumn{1}{|c|}{$\begin{array}{c}\text { ISIC-3 } \\
\text { Code }\end{array}$} \\
\hline Low (T1) & Food, Beverages and Tobacco & $15-16$ \\
& Textiles, Textile, Leather and Footwear & $17-19$ \\
& Wood and of Wood and Cork & 20 \\
& Pulp, Paper; Paper, Printing and Publishing & $21-22$ \\
& Manufacturing Nec; Recycling & $36-37$ \\
\hline
\end{tabular}


Table 2 continued

\begin{tabular}{|c|c|c|}
\hline $\begin{array}{l}\text { Technological } \\
\text { advancement }\end{array}$ & Includes subsectors: & $\begin{array}{l}\text { ISIC-3 } \\
\text { Code }\end{array}$ \\
\hline Low (T1) & $\begin{array}{l}\text { Food, Beverages and Tobacco } \\
\text { Textiles, Textile, Leather and Footwear } \\
\text { Wood and of Wood and Cork } \\
\text { Pulp, Paper; Paper, Printing and Publishing } \\
\text { Manufacturing Nec; Recycling }\end{array}$ & $\begin{array}{l}15-16 \\
17-19 \\
20 \\
21-22 \\
36-37\end{array}$ \\
\hline Middle-low (T2) & $\begin{array}{l}\text { Coke, refined petroleum and nuclear fuel } \\
\text { Rubber and plastics } \\
\text { Other Non-Metallic Mineral } \\
\text { Basic Metals and Fabricated Metal }\end{array}$ & $\begin{array}{l}23 \\
25 \\
26 \\
27-28\end{array}$ \\
\hline Middle-high (T3) & $\begin{array}{l}\text { Chemicals and chemical } \\
\text { Machinery, Nec } \\
\text { Transport Equipment }\end{array}$ & $\begin{array}{l}24 \\
29 \\
34-35\end{array}$ \\
\hline High (T4) & Electrical And Optical Equipment & $30-33$ \\
\hline
\end{tabular}

Source: own preparation on the basis of Eurostat (2011).

Table 3. Division of services industries on the basis of knowledge intensity

\begin{tabular}{|c|c|c|}
\hline $\begin{array}{c}\text { Knowledge } \\
\text { intensity }\end{array}$ & Includes industries: & $\begin{array}{c}\text { ISIC-3 } \\
\text { Code }\end{array}$ \\
\hline Low (LKI) & $\begin{array}{l}\text { Wholesale and Retail Trade } \\
\text { Hotels and Restaurants }\end{array}$ & $\begin{array}{l}\mathrm{G} \\
\mathrm{H}\end{array}$ \\
\hline Middle (KI) & $\begin{array}{l}\text { Transport and Storage } \\
\text { Financial Intermediation } \\
\text { Real Estate Activities } \\
\text { Education } \\
\text { Health and Social Work }\end{array}$ & $\begin{array}{l}60-63 \\
\mathrm{~J} \\
70 \\
\mathrm{M} \\
\mathrm{N}\end{array}$ \\
\hline High (HKI) & $\begin{array}{l}\text { Post and Telecommunications } \\
\text { Renting of M\&Eq and Other Business Activities }\end{array}$ & $\begin{array}{l}64 \\
71-74 \\
\end{array}$ \\
\hline $\begin{array}{l}\text { Other sub- } \\
\text { sectors } \\
\text { (Other) }\end{array}$ & $\begin{array}{l}\text { Public Admin and Defence; Compulsory Social Security } \\
\text { Other Community, Social and Personal Services } \\
\text { Private Households with Employed Persons } \\
\text { Extra-Territorial Organizations and Bodies }\end{array}$ & $\begin{array}{l}\mathrm{L} \\
\mathrm{O} \\
\mathrm{P} \\
\mathrm{Q}\end{array}$ \\
\hline
\end{tabular}

Source: own preparation on the basis of Eurostat (2011). 
In order to measure employment structure as precisely as possible, we will use the number of hours worked by all people engaged in a sector ${ }^{1}$. On the basis of EU-KLEMS data, employment shares will be calculated in a following way:

$$
u_{i, t}^{k} \equiv \frac{H E M P_{i, t}^{k}}{\operatorname{HEMP}_{i, t}}
$$

where:

$u_{i, t}^{k}$ - employment share of sector $k$ in country $i$ in year $t$;

$H E M P_{i, t}^{k}$ - hours worked by all people employed in sector $k$ in country $i$ in year $t$; $H E M P_{i, t}$ - hours worked by all people employed in the aggregate unit (i.e. in the whole economy, manufacturing or services).

Employment shares will serve to calculate a measure of structural similarity for every pair of countries - so called Krugman's specialization index $(K S I)$ :

$$
K S I_{i, j, t}=\sum_{k=1}^{n}\left|u_{i, t}^{k}-u_{j, t}^{k}\right|
$$

where:

$n$ is the number of sectors in consideration.

$K S I$ is commonly used in the analyses of economic specialization and structural similarities (e.g. Belke, Heine 2004; Marelli 2004) and it measures total deviation of employment shares for particular sectors for each pair of countries $i$ and $j$. KSI takes values from 0 to 2, and the higher it is, the bigger the differences between the two economies.

In order to analyse average similarities of economic structures of EU member states and tendencies of those similarities, we will calculate a simple average of $K S I$ values:

$$
A K S I_{t}=\frac{1}{m(m-1) / 2} \sum_{i=1}^{m-1} \sum_{j=i+1}^{m} K S I_{i, j, t},
$$

where:

$m$ stands for the number of countries, i.e. 15 for old member countries and 25 for the enlarged EU.

${ }^{1}$ In this way, our results will take into account possible differences in legal and economic organization of sectors between European countries. Due to those differences, relying on solely employed persons figures might lead to biased results. 
In the first step, major characteristics of $A K S I$ values for the whole economy and for manufacturing and services industries will be described.

$A K S I$, as an aggregate measure, informs us only about the average differences between economies and it does not give any information about the patterns of specialization that might occur within the sample. In order to observe such patterns and to obtain information about economic structures of groups of countries, the second stage of research will involve hierarchical clustering. Cluster analysis will enable us to distinguish groups of similar economies in terms of employment composition. Such analysis will be conducted not only in three described dimensions, but also for initial and final year of each sample, which will inform us about the dynamics of structural differences.

In order to maintain comparability of results between the cluster analysis and previous statistical description of $A K S I$ values, clusters will be distinguished on the basis of minimum average within-group distance criterion, making use of Manhattan distance formula and normalization of variables (mean equals 1 ). Due to the fact that hierarchical clustering provides only some suggestions regarding the formation of groups of similar entities, such grouping will be conducted arbitrarily, accordingly to the research purposes. In the next step, employment structures of groups will be compared, making use of average $A K S I$ values - within groups, and between groups ${ }^{2}$. In order to observe the relationships between the economic structure and development, we will also provide data on average GDP per capita for each cluster - data for this variable will come from the Penn World Tables 7.1. (Heston et al. 2012).

\section{Results of statistical analysis}

In this section main tendencies of the phenomena in consideration will be presented. Figures $1 \mathrm{a}$ and $1 \mathrm{~b}$ demonstrate average employment shares of three sectors in EU15 countries (in 1970-2006) and EU25 (1995-2006). In old member states the employment share of the primary sector was steadily decreasing - from over $17 \%$ in 1970 to about $5 \%$ in 2006 . Also the share of manufacturing and construction was diminishing - from $36 \%$ to $25 \%$ - which means that dynamic processes of deindustrialization and tertiarisation took place in Western Europe in this period. Consequently, a growing proportion of people was employed in services - in 2006 it was on average

${ }^{2}$ Within AKSI will be calculated as an average of $K S I$ for each pair of countries within a particular cluster, while Between $A K S I$ will refer to an average $K S I$ for each pair of countries belonging to different clusters. 
$70 \%$.

For the enlarged European Union the trends are less prominent, as a result, firstly, of a much shorter period of the sample and, secondly, of including in the sample both the developed and transforming economies. Nevertheless, the most important tendencies are the same as in the first case: economic role of primary and secondary sectors is declining, while employment share of the tertiary sector increased to over $65 \%$. Investigation of only 8 countries of Central and Eastern Europe (CEE) shows that employment shares and their dynamics differ significantly from those in the rest of the European Union. In CEE the share of primary sector declined in 1995-2006 from $14 \%$ to $9 \%$, while the one of the tertiary sector grew from $53 \%$ to $59 \%$. However, we do not observe a systematic deindustrialization in this region, with employment share of secondary sectors continuously maintained at ca. $32 \%$. It indicates the diversity of phases of economic development between the two regions of Europe.

Figures 1a and 1b. Shares of three sectors in total employment in EU15 (19702006, left) and EU25 countries (1995-2006, right)
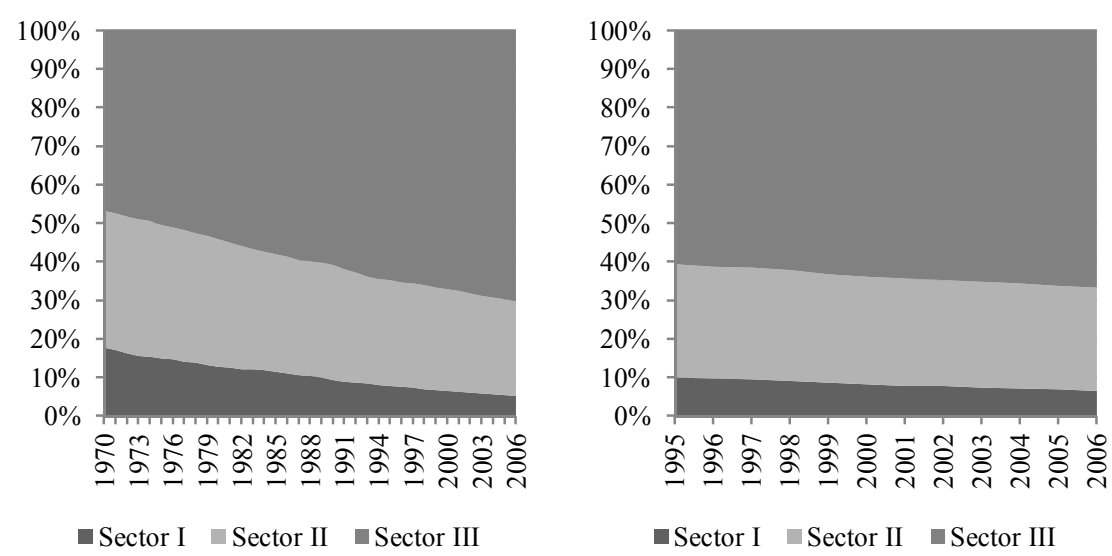

Source: own preparation on the basis of EU-KLEMS data.

In the second step, we will discuss changes in the differences of employment shares. Figure 2 presents changes of $A K S I$ values in EU15 and EU25: 
Figure 2. AKSI values for economies of UE15 (1970-2006) and UE25 (1995-2006)



Source: own preparation on the basis of EU-KLEMS data.

The declining value of $A K S I$ indicates that economies of old member states were getting more and more similar to each other. A large part of this homogenization took place in 1970-1990, while diversity of structures has stabilized since early 1990's. In the EU25 sample, we can observe only a slight decrease of $A K S I$ values, which probably means that structural transformation in transition economies was on average not dynamic enough for the structural distance from the Western Europe to diminish.

Similar analysis will be conducted for manufacturing and services subsectors. Employment in manufacturing throughout the whole period of interest was dominated by subsectors of low or medium-low technological advancement, although their share was steadily decreasing - in EU15 from $72 \%$ to $65 \%$ on average. Along the development path, the labour force was moving towards high technology subsectors. Comparison of Figures $3 \mathrm{a}$ and $3 \mathrm{~b}$ leads us to the observation that new member states employ on average relatively fewer people in high technology subsectors. 
Figures 3a and 3b. Shares of manufacturing industries of different technological advancement in total employment in manufacturing in EU15 (1970-2006, left) and EU25 countries (1995-2006, right)
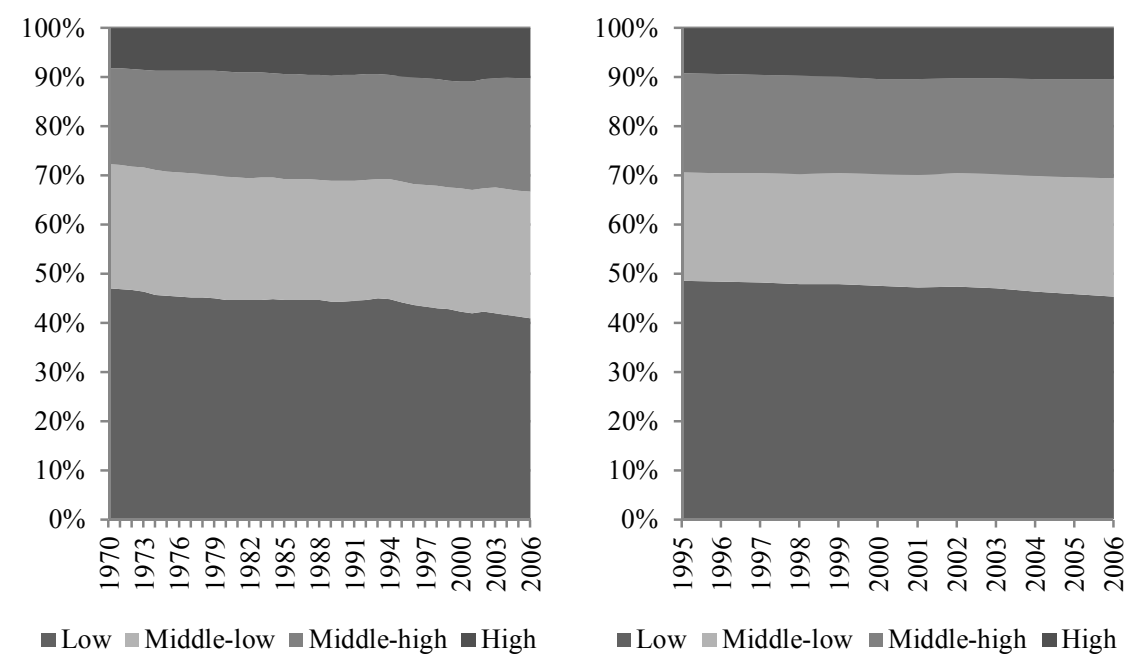

Source: own preparation on the basis of EU-KLEMS data.

Observation of $A K S I$ values in manufacturing (Figure 4) leads us to some interesting insights. Firstly, they are relatively high - up to 0,35 (with values for whole economy lower than 0,25), which suggests high technological diversity in European manufacturing. Secondly, this diversity has been slowly, yet steadily, declining since 1984. Thirdly, in the EU25 sample an opposite tendency has been taking place. It can possible indicate that new member countries did not manage to keep up with modernization of manufacturing structure with Western Europe. 
Figure 4. AKSI values for manufacturing of EU15 (1970-2006) and EU25 (19952006)

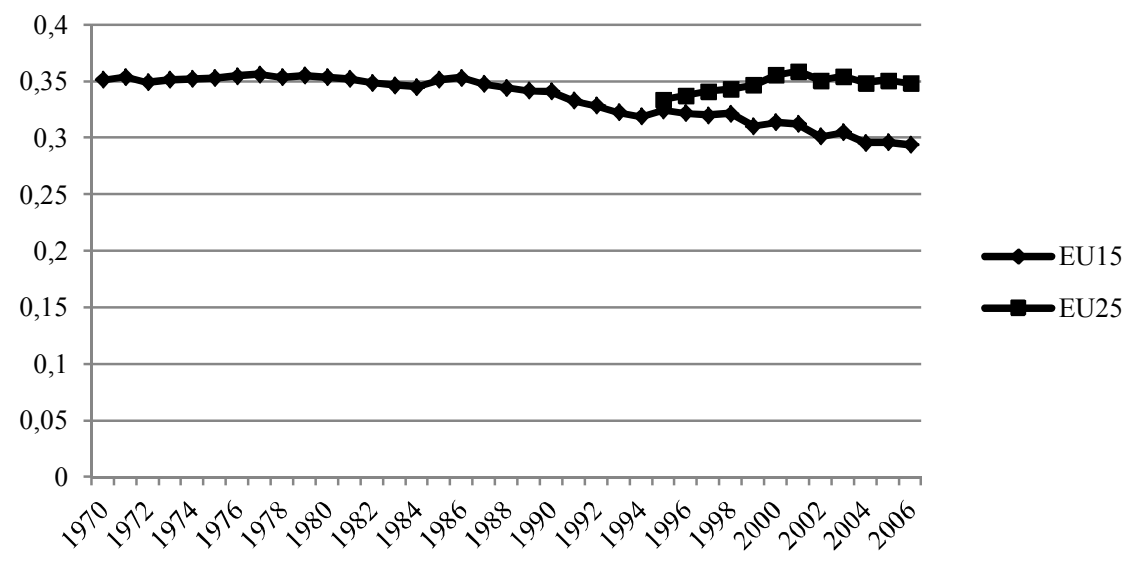

Source: own preparation on the basis of EU-KLEMS data.

The dynamics of structural change in services was higher compared to manufacturing (Figures 5a and 5b). In EU15 countries, employment shares of industries with low knowledge intensity diminished significantly during the period of analysis. At the same time, the employment share of high knowledge intensity subsectors increased twofold, to $19 \%$. The role of other subsectors, mainly the public services, remained stable. Similar tendencies took place in the wider sample of countries - here in 2006 industries of high knowledge intensity employed on average about $16 \%$ of total employment in services. 
Figures 5a and 5b. Shares of services industries of different knowledge intensity in total employment in services in EU15 (1970-2006, left) and EU25 countries (19952006, right)
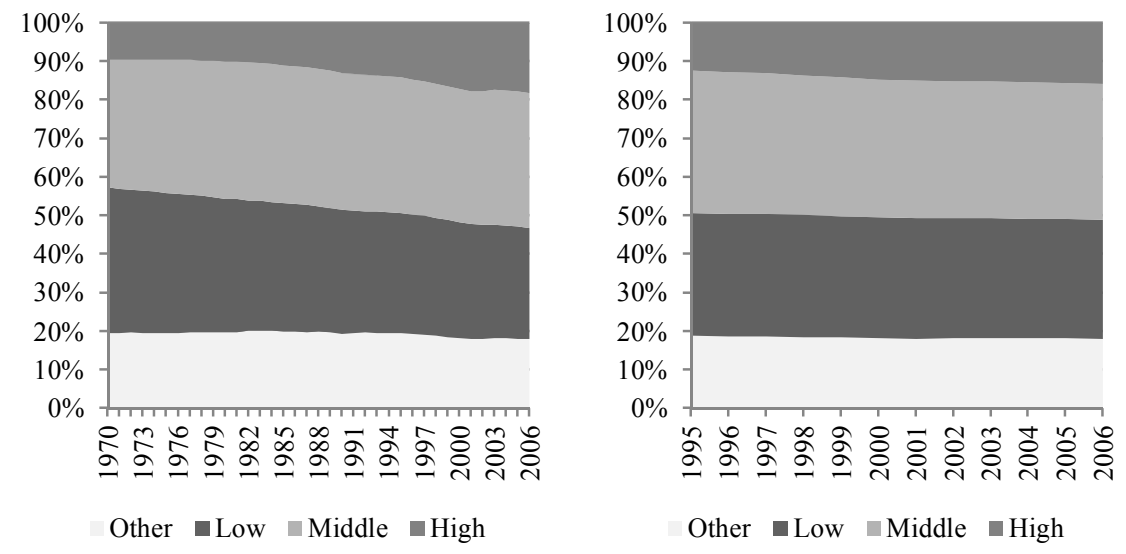

Source: own preparation on the basis of EU-KLEMS data.

Conversely to manufacturing, diversity of knowledge intensity in services was increasing, with the exception of the period of 1987-1994, when it was fairly constant (Figure 6). Nonetheless, this diversity was in the whole period much lower than one in manufacturing. What is interesting, in the case of services values of $A K S I$ for EU25 were even slightly lower than for EU15, and they were stable.

Figure 6. AKSI values for services of EU15 (1970-2006) and EU25 (1995-2006)

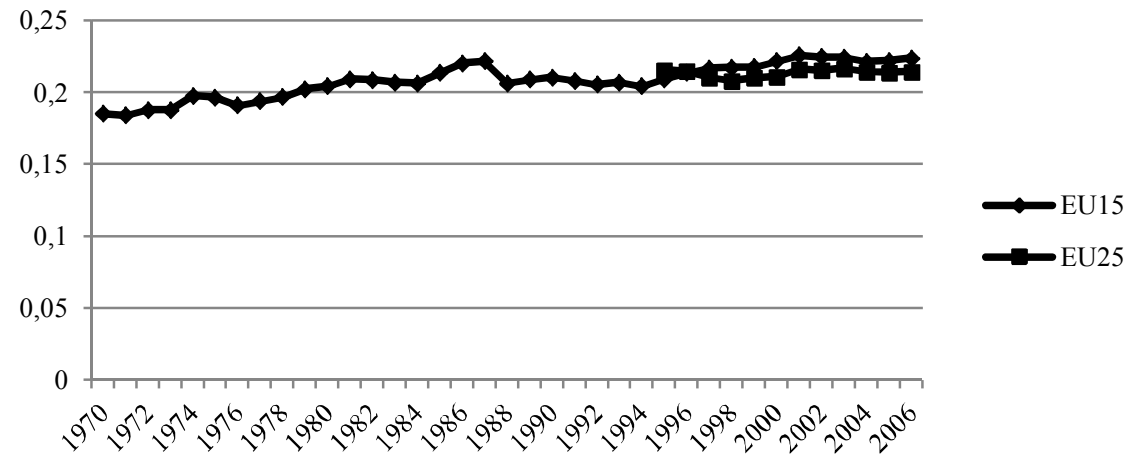

Source: own preparation on the basis of EU-KLEMS data. 


\section{Results of cluster analysis}

Firstly, we conducted cluster analysis for the economies of EU15 in 1970 and in 2006. It demonstrated clearly that in 1970 the European Union was divided into two groups of economies - traditional and modern ones (Table $4)^{3}$. Cluster no. 1 comprised less developed economies, i.e. the Mediterranean countries, Austria, Ireland and Finland, which were characterized by a high share of primary sector in employment. In more developed 'Northern' economies the role of traditional sectors was much lower, with higher employment shares of manufacturing and services.

Table 4. Distribution of EU15 economies into clusters, based on employment shares of three economic sectors, 1970

\begin{tabular}{|c|l|c|c|c|r|r|}
\hline No. & \multicolumn{1}{|c|}{ Countries } & S1 & S2 & S3 & $\begin{array}{c}\text { Av. GDP p. c. } \\
\text { (USD 2005) }\end{array}$ & $\begin{array}{c}\text { Within } \\
\text { AKSI }\end{array}$ \\
\hline $\mathbf{1}$ & $\begin{array}{l}\text { AUT, ESP, FIN, FRA, } \\
\text { GRC, IRL, ITA, PRT }\end{array}$ & $26,2 \%$ & $32,7 \%$ & $41,0 \%$ & 12856 & 0,156 \\
\hline $\mathbf{2}$ & $\begin{array}{l}\text { BEL, DNK, GER, LUX, } \\
\text { NLD, SWE, UK }\end{array}$ & $8,0 \%$ & $38,8 \%$ & $53,2 \%$ & 17985 & 0,146 \\
\hline & & & & & Between AKSI & 0,369 \\
\hline
\end{tabular}

Source: own preparation on the basis of EU-KLEMS data.

After over 30 years, EU economies have become much more similar to each other (Table 5). However, the division into country groups seems to be persistent. We distinguished three clusters, with one (of Greece and Portugal) clearly standing out from the rest. The two remaining groups, close in composition to clusters from 1970, with slight differences in the extent of tertiarisation, can be qualified as modern economies.

${ }^{3}$ Country codes are as follows: AUT Austria, BEL Belgium, CYP Cyprus, CZE Czech Republic, DNK Denmark, EST Estonia, ESP Spain, FIN Finland, FRA France, GER Germany, GRC Greece, HUN Hungary, IRL Ireland, ITA Italy, LTU Lithuania, LVA Latvia, LUX Luxembourg, MLT Malta, NLD Netherlands, POL Poland, PRT Portugal, SVK Slovakia, SVN Slovenia, SWE Sweden, UK United Kingdom. 
Table 5. Distribution of EU15 economies into clusters, based on employment shares of three economic sectors, 2006

\begin{tabular}{|c|l|c|c|c|r|r|}
\hline No. & \multicolumn{1}{|c|}{ Countries } & S1 & S2 & S3 & $\begin{array}{c}\text { Av. GDP p. c. } \\
\text { (USD 2005) }\end{array}$ & $\begin{array}{c}\text { Within } \\
\text { AKSI }\end{array}$ \\
\hline $\mathbf{1}$ & GRC, PRT & $12,1 \%$ & $26,1 \%$ & $61,8 \%$ & 23477 & 0,126 \\
\hline $\mathbf{2}$ & $\begin{array}{l}\text { AUT, ESP, FIN, FRA, } \\
\text { IRL, ITA, NLD }\end{array}$ & $5,9 \%$ & $25,3 \%$ & $68,8 \%$ & 34361 & 0,113 \\
\hline $\mathbf{3}$ & $\begin{array}{l}\text { BEL, DNK, GER, LUX, } \\
\text { SWE, UK }\end{array}$ & $2,5 \%$ & $23,2 \%$ & $74,3 \%$ & 41596 & 0,069 \\
\hline & & & & & Between AKSI & 0,165 \\
\hline
\end{tabular}

Source: own preparation on the basis of EU-KLEMS data.

The new member states in 1995 had very diverse economic structures (Table 6). Four of them constituted a separate cluster, with a very high share of primary sector in employment. The rest of them, besides Malta, formed altogether with some of the Western economies a cluster at an intermediate level of tertiarisation. The most modern cluster, with a very limited share of primary sector, included almost only old member countries.

Table 6. Distribution of EU25 economies into clusters, based on employment shares of three economic sectors, 1995

\begin{tabular}{|c|l|c|c|c|c|c|}
\hline No. & \multicolumn{1}{|c|}{ Countries } & S1 & S2 & S3 & $\begin{array}{c}\text { Av. GDP p. c. } \\
\text { (USD 2005) }\end{array}$ & $\begin{array}{c}\text { Within } \\
\text { AKSI }\end{array}$ \\
\hline $\mathbf{1}$ & CYP, LTU, POL, SVN & $20,1 \%$ & $30,7 \%$ & $49,2 \%$ & 12388 & 0,156 \\
\hline $\mathbf{2}$ & $\begin{array}{l}\text { AUT, CZE, ESP, EST, } \\
\text { FIN, FRA, GRE, HUN, } \\
\text { IRE, ITA, LVA, PRT, } \\
\text { SVK, }\end{array}$ & $10,9 \%$ & $29,8 \%$ & $59,3 \%$ & & \\
\hline $\mathbf{3}$ & $\begin{array}{l}\text { BEL, DNK, GER, LUX, } \\
\text { MLT, NLD, SWE, UK }\end{array}$ & $3,7 \%$ & $27,9 \%$ & $68,3 \%$ & 29101 & 0,096 \\
\hline & & & & & Between AKSI & 0,243 \\
\hline
\end{tabular}

Source: own preparation on the basis of EU-KLEMS data.

Until 2006 the most important characteristics of this description did not change (Table 7). Greece and Portugal, which did not manage to reform their economies, joined the cluster of traditional economies. Poland, due to an exceptionally high share of employment in primary sector, became an outlying economy in the whole sample. 
Table 7. Distribution of EU25 economies into clusters, based on employment shares of three economic sectors, 2006

\begin{tabular}{|c|l|c|c|c|r|r|}
\hline No. & \multicolumn{1}{|c|}{ Countries } & S1 & S2 & S3 & $\begin{array}{c}\text { Av. GDP p. c. } \\
\text { (USD 2005) }\end{array}$ & $\begin{array}{c}\text { Within } \\
\text { AKSI }\end{array}$ \\
\hline $\mathbf{1}$ & $\begin{array}{l}\text { CYP, GRE, LTU, PRT, } \\
\text { SVN }\end{array}$ & $11,5 \%$ & $27,8 \%$ & $60,7 \%$ & 20806 & 0,163 \\
\hline $\mathbf{2}$ & $\begin{array}{l}\text { AUT, CZE, ESP, EST, } \\
\text { FIN, FRA, HUN, IRE, } \\
\text { ITA, LVA, SVK }\end{array}$ & $5,6 \%$ & $29,2 \%$ & $65,1 \%$ & 26336 & 0,120 \\
\hline $\mathbf{3}$ & $\begin{array}{l}\text { BEL, DNK, GER, LUX, } \\
\text { MLT, NLD, SWE, UK }\end{array}$ & $2,9 \%$ & $23,1 \%$ & $74,0 \%$ & 38471 & 0,076 \\
\hline $\mathbf{4}$ & POL & $23,5 \%$ & $25,3 \%$ & $51,1 \%$ & 14064 & - \\
\hline & & & & & Between AKSI & 0,226 \\
\hline
\end{tabular}

Source: own preparation on the basis of EU-KLEMS data.

The essential conclusion from the depicted analysis is that European economies are now at different phases of development and that such diversity is a quite persistent phenomenon. Within-heterogeneity of clusters remains relatively low, while between-heterogeneity declines slowly. Additionally, we can observe that economic structure is clearly related to the development level - the higher the average GDP per capita in a cluster, the higher the extent of tertiarisation.

Cluster analysis conducted for manufacturing industries leads us again to distinguishing two groups of countries, at different levels of technological advancement. In 1970 the least developed countries of Western Europe (except for Ireland, which is an outlier in the case of manufacturing structure) specialised in low-tech activities, while manufacturing structure of more developed economies was clearly biased in favour of more advanced industries. The division depicted in Table 8 corresponds to a large extent with the one for whole economy (Table 4). 
Table 8. Distribution of EU15 economies into clusters, based on employment shares of manufacturing subsectors, 1970

\begin{tabular}{|c|l|c|c|c|c|r|r|}
\hline No. & \multicolumn{1}{|c|}{ Countries } & T1 & T2 & T3 & T4 & $\begin{array}{c}\text { Av. GDP p.c. } \\
\text { (USD 2005) }\end{array}$ & $\begin{array}{c}\text { Within } \\
\text { AKSI }\end{array}$ \\
\hline $\mathbf{1}$ & $\begin{array}{l}\text { ESP, FIN, GRE, } \\
\text { PRT }\end{array}$ & $60,6 \%$ & $19,4 \%$ & $15,8 \%$ & $4,1 \%$ & 11490 & 0,199 \\
\hline $\mathbf{2}$ & $\begin{array}{l}\text { AUT, BEL, DNK, } \\
\text { FRA, GER, ITA, } \\
\text { NLD, SWE, UK }\end{array}$ & $43,9 \%$ & $23,9 \%$ & $22,5 \%$ & $9,7 \%$ & 16524 & 0,178 \\
\hline $\mathbf{3}$ & IRL & $50,0 \%$ & $16,6 \%$ & $17,4 \%$ & $16,0 \%$ & 10954 & - \\
\hline $\mathbf{4}$ & LUX & $19,1 \%$ & $69,4 \%$ & $8,9 \%$ & $2,7 \%$ & 23111 & - \\
\hline & & & & & & Between $\boldsymbol{A K S I}$ & 0,465 \\
\hline
\end{tabular}

Source: own preparation on the basis of EU-KLEMS data.

During the period 1970-2006 Spain and Finland managed to modernize their manufacturing sector, so that they joined the intermediate cluster (Table 9). Conversely, Portugal and Greece did not change their manufacturing structures almost at all, and they constitute together a low-tech cluster. At the same time, Germany and Sweden became the new leaders in the European manufacturing, with limited role of low-tech industries. $A K S I$ values indicate a very high and increasing internal homogeneity of particular clusters and high differences between them.

Table 9. Distribution of EU15 economies into clusters, based on employment shares of manufacturing subsectors, 2006

\begin{tabular}{|c|l|c|c|c|c|r|r|}
\hline No. & \multicolumn{1}{|c|}{ Countries } & T1 & T2 & T3 & T4 & $\begin{array}{c}\text { Av. GDP p.c. } \\
\text { (USD 2005) }\end{array}$ & $\begin{array}{c}\text { Within } \\
\text { AKSI }\end{array}$ \\
\hline $\mathbf{1}$ & GRE, PRT & $62,7 \%$ & $20,7 \%$ & $13,0 \%$ & $3,6 \%$ & 23477 & 0,073 \\
\hline $\mathbf{2}$ & $\begin{array}{l}\text { AUT, BEL, DNK, } \\
\text { ESP, FIN, FRA, } \\
\text { ITA, NLD, UK }\end{array}$ & $39,5 \%$ & $25,7 \%$ & $24,5 \%$ & $10,2 \%$ & 33862 & 0,115 \\
\hline $\mathbf{3}$ & GER, SWE & $31,0 \%$ & $23,7 \%$ & $33,2 \%$ & $12,2 \%$ & 34148 & 0,088 \\
\hline $\mathbf{4}$ & IRL & $39,8 \%$ & $18,0 \%$ & $19,8 \%$ & $22,4 \%$ & 41159 & - \\
\hline $\mathbf{5}$ & LUX & $31,1 \%$ & $49,9 \%$ & $11,3 \%$ & $7,7 \%$ & 75899 & - \\
\hline & & & & & & Between AKSI & 0,440 \\
\hline
\end{tabular}

Source: own preparation on the basis of EU-KLEMS data.

In the case of EU25 sample, the number of distinguished clusters is higher, however the division according to technological advancement is clear (Table 10). In 1995 the manufacturing structures of most of the new member 
states were dominated by low-tech industries, which made them similar to some of the Mediterranean countries. Only the Czech Republic, Slovakia and Slovenia and, to some extent, Hungary had a relatively modern structure of manufacturing.

Table 10. Distribution of EU25 economies into clusters, based on employment shares of manufacturing subsectors, 1995

\begin{tabular}{|c|l|c|c|c|r|r|r|}
\hline No. & \multicolumn{1}{|c|}{ Countries } & T1 & T2 & T3 & T4 & $\begin{array}{c}\text { Av. GDP p.c. } \\
\text { (USD 2005) }\end{array}$ & $\begin{array}{c}\text { Within } \\
\text { AKSI }\end{array}$ \\
\hline $\mathbf{1}$ & $\begin{array}{l}\text { CYP, EST, GRE, } \\
\text { LTU, LVA, PRT }\end{array}$ & $67,4 \%$ & $14,7 \%$ & $13,2 \%$ & $4,7 \%$ & 11806 & 0,158 \\
\hline $\mathbf{2}$ & ESP, POL & $49,3 \%$ & $22,9 \%$ & $21,1 \%$ & $6,7 \%$ & 15145 & 0,075 \\
\hline $\mathbf{3}$ & FIN, HUN, MLT & $49,6 \%$ & $17,2 \%$ & $21,2 \%$ & $12,0 \%$ & 16879 & 0,140 \\
\hline $\mathbf{4}$ & $\begin{array}{l}\text { AUT, BEL, CZE, } \\
\text { DNK, FRA, ITA, } \\
\text { NLD, SVK, SVN, } \\
\text { UK }\end{array}$ & $42,5 \%$ & $24,6 \%$ & $22,9 \%$ & $10,1 \%$ & 23384 & 0,103 \\
\hline $\mathbf{5}$ & GER, SWE & $34,5 \%$ & $21,9 \%$ & $30,8 \%$ & $12,7 \%$ & 27070 & 0,092 \\
\hline $\mathbf{6}$ & IRL & $24,2 \%$ & $60,0 \%$ & $10,5 \%$ & $5,3 \%$ & 51367 & - \\
\hline $\mathbf{7}$ & LUX & $46,9 \%$ & $15,4 \%$ & $18,2 \%$ & $19,5 \%$ & 22303 & - \\
\hline & & & & & & Between AKSI & 0,394 \\
\hline
\end{tabular}

Source: own preparation on the basis of EU-KLEMS data.

The division presented above is highly persistent, with only a few countries changing their position during the 1995-2006 period (Table 11). Manufacturing structure of the Czech Republic and Slovakia is worth mentioning - together with Finland they constituted one of the clusters with a big role of high-tech industries. Conversely, Poland together with Belgium and Spain form a group with a dominant role of traditional activities.

Table 11. Distribution of EU25 economies into clusters, based on employment shares of manufacturing subsectors, 2006

\begin{tabular}{|c|c|c|c|c|c|r|r|}
\hline No. & Countries & T1 & T2 & T3 & T4 & $\begin{array}{c}\text { Av. GDP p.c. } \\
\text { (USD 2005) }\end{array}$ & $\begin{array}{c}\text { Within } \\
\text { AKSI }\end{array}$ \\
\hline $\mathbf{1}$ & $\begin{array}{l}\text { CYP, EST, GRE, } \\
\text { LVA, LTU, PRT }\end{array}$ & $65,7 \%$ & $18,7 \%$ & $11,5 \%$ & $4,2 \%$ & 18469 & 0,142 \\
\hline $\mathbf{2}$ & BEL, ESP, POL & $43,1 \%$ & $26,6 \%$ & $23,4 \%$ & $6,8 \%$ & 25940 & 0,211 \\
\hline $\mathbf{3}$ & HUN, IRL, MLT & $43,2 \%$ & $18,7 \%$ & $17,5 \%$ & $20,6 \%$ & 26338 & 0,160 \\
\hline
\end{tabular}


Table 11 continued

\begin{tabular}{|c|l|c|c|c|c|r|r|}
\hline No. & \multicolumn{1}{|c|}{ Countries } & T1 & T2 & T3 & T4 & $\begin{array}{c}\text { Av. GDP p.c. } \\
\text { (USD 2005) }\end{array}$ & $\begin{array}{c}\text { Within } \\
\text { AKSI }\end{array}$ \\
\hline $\mathbf{4}$ & $\begin{array}{l}\text { AUT, DNK, FRA, } \\
\text { ITA, NLD, SVN, } \\
\text { UK }\end{array}$ & $39,5 \%$ & $25,9 \%$ & $23,9 \%$ & $10,7 \%$ & 33102 & 0,085 \\
\hline $\mathbf{5}$ & CZE, FIN, SVK & $36,6 \%$ & $25,9 \%$ & $22,5 \%$ & $15,1 \%$ & 24002 & 0,107 \\
\hline $\mathbf{6}$ & GER, SWE & $31,0 \%$ & $23,7 \%$ & $33,2 \%$ & $12,2 \%$ & 34148 & 0,088 \\
\hline $\mathbf{7}$ & LUX & $31,1 \%$ & $49,9 \%$ & $11,3 \%$ & $7,7 \%$ & 75899 & - \\
\hline \multicolumn{7}{|r}{} \\
\hline
\end{tabular}

Source: own preparation on the basis of EU-KLEMS data.

Cluster analysis conducted for structure of services demonstrates the strength of geographical patterns of development. In the Southern European countries services of low knowledge intensity engaged in 1970 an above average shares of employment; similar was the case of other services (i.e. mainly public administration). This fact can be attributed to some extent to the big role of tourism in this region. The Scandinavian economies were characterized by a high share of medium-knowledge intensity services, like education and health care. France and Great Britain were the leaders in terms of high-knowledge intensity services. Distinguished clusters are characterized by high internal homogeneity, however the differences between them are not that evident.

Table 12. Distribution of EU15 economies into clusters, based on employment shares of services subsectors, 1970

\begin{tabular}{|c|l|c|c|c|c|r|r|}
\hline No. & Countries & LKI & KI & HKI & Other & $\begin{array}{c}\text { Av. GDP p.c. } \\
\text { (USD 2005) }\end{array}$ & $\begin{array}{c}\text { Within } \\
\text { AKSI }\end{array}$ \\
\hline $\mathbf{1}$ & ESP, ITA, PRT & $46,5 \%$ & $27,1 \%$ & $6,0 \%$ & $20,4 \%$ & 11393 & 0,161 \\
\hline $\mathbf{2}$ & $\begin{array}{l}\text { AUT, GER, } \\
\text { GRE, IRE, } \\
\text { LUX, NLD }\end{array}$ & $36,9 \%$ & $33,0 \%$ & $10,0 \%$ & $20,1 \%$ & 16347 & 0,092 \\
\hline $\mathbf{3}$ & $\begin{array}{l}\text { DNK, FIN, } \\
\text { SWE }\end{array}$ & $34,9 \%$ & $40,2 \%$ & $8,3 \%$ & $16,5 \%$ & 17022 & 0,096 \\
\hline $\mathbf{4}$ & FRA, UK & $34,6 \%$ & $33,6 \%$ & $14,5 \%$ & $17,2 \%$ & 14867 & 0,049 \\
\hline $\mathbf{5}$ & BEL & $31,9 \%$ & $30,2 \%$ & $11,1 \%$ & $26,8 \%$ & 15679 & - \\
\hline \multicolumn{7}{|l|}{} \\
\hline
\end{tabular}

Source: own preparation on the basis of EU-KLEMS data. 
During the 1970-2006 period the division into clusters was subject to some changes, i.a. the differences between groups increased. The cluster of Southern Europe economies was complemented by Italy and it still specialized in low knowledge intensity services. On the other end of the scale, there are countries placed in the centre of Europe, with a big role of high knowledge intensity activities.

Table 13. Distribution of EU15 economies into clusters, based on employment shares of services subsectors, 2006

\begin{tabular}{|c|l|c|c|c|c|r|c|}
\hline No. & \multicolumn{1}{|c|}{ Countries } & LKI & KI & HKI & Other & $\begin{array}{c}\text { Av. GDP p.c. } \\
\text { (USD 2005) }\end{array}$ & $\begin{array}{c}\text { Within } \\
\text { AKSI }\end{array}$ \\
\hline $\mathbf{1}$ & $\begin{array}{l}\text { ESP, GRE, ITA, } \\
\text { PRT }\end{array}$ & $37,9 \%$ & $27,3 \%$ & $14,2 \%$ & $20,5 \%$ & 26515 & 0,153 \\
\hline $\mathbf{2}$ & $\begin{array}{l}\text { AUT, DNK, FIN, } \\
\text { IRE, SWE, LUX }\end{array}$ & $26,0 \%$ & $40,7 \%$ & $17,3 \%$ & $16,0 \%$ & 43211 & 0,135 \\
\hline $\mathbf{3}$ & $\begin{array}{l}\text { BEL, FRA, GER, } \\
\text { NLD, UK }\end{array}$ & $25,1 \%$ & $34,4 \%$ & $22,2 \%$ & $18,2 \%$ & 34347 & 0,095 \\
\hline \multicolumn{7}{|c}{} \\
\hline
\end{tabular}

Source: own preparation on the basis of EU-KLEMS data.

Compared to old member countries, most of the Central and Eastern Europe economies are characterized by low share of high knowledge intensive services - in 1995 four of them formed a separate cluster. On the other hand, they also differed from the Mediterranean countries, due to small employment in subsectors with low knowledge intensity. Similarly to the case of manufacturing, the Czech Republic, Slovakia and Slovenia have a relatively modern employment structures in services, which situates them close to the leaders of old Europe (Table 14).

Table 14. Distribution of EU25 economies into clusters, based on employment shares of services subsectors, 1995

\begin{tabular}{|c|l|c|c|c|c|r|r|}
\hline No. & \multicolumn{1}{|c|}{ Countries } & LKI & KI & HKI & Other & $\begin{array}{c}\text { Av. GDP p.c. } \\
\text { (USD 2005) }\end{array}$ & $\begin{array}{c}\text { Within } \\
\text { AKSI }\end{array}$ \\
\hline $\mathbf{1}$ & $\begin{array}{l}\text { ESP, GRE, ITA, } \\
\text { PRT }\end{array}$ & $39,4 \%$ & $27,8 \%$ & $11,3 \%$ & $21,5 \%$ & 20481 & 0,108 \\
\hline $\mathbf{2}$ & $\begin{array}{l}\text { AUT, CZE, GER, } \\
\text { IRE, LUX, MLT, } \\
\text { SVN }\end{array}$ & $33,4 \%$ & $35,2 \%$ & $13,5 \%$ & $17,9 \%$ & 25478 & 0,099 \\
\hline $\mathbf{3}$ & $\begin{array}{l}\text { EST, HUN, LTU, } \\
\text { POL }\end{array}$ & $31,9 \%$ & $41,8 \%$ & $8,7 \%$ & $17,6 \%$ & 8794 & 0,120 \\
\hline
\end{tabular}


Table 14 continued

\begin{tabular}{|r|l|r|r|r|r|r|r|}
\hline No. & \multicolumn{1}{|c|}{ Countries } & LKI & KI & HKI & Other & $\begin{array}{c}\text { Av. GDP p.c. } \\
\text { (USD 2005) }\end{array}$ & $\begin{array}{c}\text { Within } \\
\text { AKSI }\end{array}$ \\
\hline $\mathbf{4}$ & $\begin{array}{l}\text { BEL, FRA, NLD, } \\
\text { UK }\end{array}$ & $27,1 \%$ & $34,5 \%$ & $19,1 \%$ & $19,4 \%$ & 27134 & 0,103 \\
\hline $\mathbf{5}$ & $\begin{array}{l}\text { DNK, FIN, SVK, } \\
\text { SWE }\end{array}$ & $24,6 \%$ & $44,7 \%$ & $12,5 \%$ & $18,3 \%$ & 21965 & 0,047 \\
\hline $\mathbf{6}$ & LVA & $23,9 \%$ & $47,2 \%$ & $7,3 \%$ & $21,6 \%$ & 6019 & - \\
\hline $\mathbf{7}$ & CYP & $44,6 \%$ & $32,8 \%$ & $4,3 \%$ & $18,4 \%$ & 15553 & - \\
\hline
\end{tabular}

Source: own preparation on the basis of EU-KLEMS data.

Cluster analysis for EU25 in 2006 indicates that a few, clearly geographical groups took shape: Baltic, Scandinavian and Centre of Europe countries are characterized by distinct specialization patterns. Additionally, a big group of 12 countries has been distinguished, with an intermediate composition of services. This cluster includes both old and new member states. The latter ones became very homogenous, i.a. in 2006 all CEE countries (the Czech Republic, Hungary, Poland, Slovakia and Slovenia) were situated in one cluster (Table 15).

Table 15. Distribution of EU25 economies into clusters, based on employment shares of services subsectors, 2006

\begin{tabular}{|c|l|r|r|r|r|r|r|}
\hline No. & \multicolumn{1}{|c|}{ Countries } & LKI & KI & HKI & Other & $\begin{array}{c}\text { Av. GDP p.c. } \\
\text { (USD 2005) }\end{array}$ & $\begin{array}{c}\text { Within } \\
\text { AKSI }\end{array}$ \\
\hline $\mathbf{1}$ & CYP, PRT & $43,7 \%$ & $26,9 \%$ & $7,5 \%$ & $21,9 \%$ & 19387 & 0,225 \\
\hline $\mathbf{2}$ & EST, LTU, LVA & $33,4 \%$ & $39,7 \%$ & $8,9 \%$ & $18,1 \%$ & 15078 & 0,079 \\
\hline $\mathbf{3}$ & $\begin{array}{l}\text { AUT, CZE, ESP, } \\
\text { GER, GRE, HUN, } \\
\text { IRE, ITA, MLT, } \\
\text { POL, SVK, SVN }\end{array}$ & $32,6 \%$ & $33,1 \%$ & $16,1 \%$ & $18,2 \%$ & 25999 & 0,122 \\
\hline $\mathbf{4}$ & $\begin{array}{l}\text { BEL, FRA, NLD, } \\
\text { UK }\end{array}$ & $24,7 \%$ & $34,2 \%$ & $23,0 \%$ & $18,1 \%$ & 42941 & 0,089 \\
\hline $\mathbf{5}$ & DNK, FIN, SWE & $23,2 \%$ & $43,8 \%$ & $16,5 \%$ & $16,4 \%$ & 34953 & 0,061 \\
\hline $\mathbf{6}$ & LUX & $24,8 \%$ & $40,5 \%$ & $21,0 \%$ & $13,7 \%$ & 75899 & - \\
\hline
\end{tabular}

Source: own preparation on the basis of EU-KLEMS data. 


\section{Conclusions}

In the article, the structural similarities of the economies of the European Union have been described. It was shown that the economies of the EU15 became increasingly homogenous and that the initial significant differences between the two clusters: the traditional and modern ones were significantly reduced. Only Greece and Portugal are clearly divergent from other countries with an above-average share of the primary sector. The economic structure is strongly associated with the level of GDP, which confirms the theoretical predictions.

Most of the new member states in 1995 were characterized by traditional or intermediate economic structure. Changes in them in 1995-2006 mainly consisted in reducing the role of the primary sector, in the absence of deindustrialization, so the differences between them and the Western Europe have been reduced only to a small extent. Poland, due to a very slow structural change became an outlying economy with an expanded traditional sector.

Also in the manufacturing structure of the EU15 a progressing homogenization was observed, while the opposite trend took place in the structure of services. Cluster analysis showed that the internal composition of these two sectors only to a limited extent follows a similar pattern as the structure of the entire economy. It is correlated with the level of GDP, however the impact of the geographical specificity is clear - the countries of Southern Europe, Baltic States and the Nordic region are characterized by distinct structural patterns. This fact, as well as the persistence of division into clusters, underlines the role of historical and cultural factors in shaping the economic structure. New member states were usually located in clusters of traditional economies, except for the Czech Republic, Slovakia and Slovenia, which are characterized by a favorable structure of the economy and manufacturing.

These observations confirm the validity of basic predictions of the sectoral theories, but at the same time reveal the specific nature of the formation of the structure of manufacturing and services. In this way, the article provides conclusions and suggests new inquiry directions for the research project.

\section{References}

Belke A., Heine J.M. (2004), Specialisation Patterns and the Synchronicity of Regional Employment Cycles in Europe, "IZA Discussion Papers", No. 1439.

Chenery H.B. (1982), Industrialization and Growth: The Experience of Large Countries, "World Bank Staff Working Papers", No. 539. 
Chenery H.B., Taylor L. (1968), Development Patterns: Among Countries and Over Time, "The Review of Economics and Statistics", Vol. 50, No. 4, http://dx.doi.org/10.2307/1926806.

Chenery H.B., Watanabe T. (1958), International Comparisons of the Structure of Production, "Econometrica", Vol. 26, No. 4, http://dx.doi.org/10.2307/1907514.

Clark C. (1951), Conditions of Economic Progress, MacMillan \& Co. Ltd, London.

Cornwall J., Cornwall W. (1994), Growth Theory and Economic Structure, "Economica", Vol. 61, No. 242, http://dx.doi.org/10.2307/2554960.

Döhrn R., Heilemann U. (1996), The Chenery hypothesis and structural change in Eastern Europe, "Economics of Transition", Vol. 4, Issue 2, http://dx.doi.org/10.1111/j.1468-0351.1996.tb00180.x.

ECB, MPC task force of the ESCB (2004), Sectoral Specialisation in the EU: A Macroeconomic Perspective, "Occasional Paper Series", No. 19.

Eurostat (2011). High technology and knowledge-intensive sectors. http://epp.eurostat.ec.europa.eu/cache/ITY_SDDS/Annexes/hrst_st_esms_an9.pd $\mathrm{f}(02.06 .2013)$.

Heston A., Summers R., Aten B. (2012), Penn World Table Version 7.1, Center for International Comparisons of Production, Income and Prices at the University of Pennsylvania.

Höhenberger N., Schmiedeberg, C. (2008), Structural Convergence of European Countries, "Center for European, Governance and Economic Development Research Discussion Papers", No. 75.

Kenessey Z. (1987). The Primary, Secondary, Tertiary and Quaternary Sectors of the Economy, "Review of Income and Wealth", Vol. 33, Issue 4, http://dx.doi.org/10.1111/j.1475-4991.1987.tb00680.x.

Kuznets S. (1949), National Income and Industrial Structure, "Econometrica", Vol. 17, http://dx.doi.org/10.2307/1907310.

Kuznets S. (1980), Driving Forces of Economic Growth: What Can We Learn from History?, "Weltwirtschaftliches Archiv", Vol. 116, Issue 3, http://dx.doi.org/ 10.1007/BF02708815.

Landesmann M. (2000), Structural Change in the Transition Economies, 1989 to 1999, "wiiw Research Reports", No. 269.

Malerba F. (2002), Sectoral systems of innovation and production, "Research Policy", Vol. 31, Issue 2, http://dx.doi.org/10.1016/S0048-7333(01)00139-1.

Marelli E. (2004). Evolution of employment structures and regional specialisation in the EU. "Economic Systems", Vol. 28, Issue 1, http://dx.doi.org/10.101 6/j.ecosys.2004.01.004.

Mickiewicz T., Zalewska A. (2005), De-industrialisation and the Post-Communist Transition: Rowthorn and Wells' Model Revisited, "CSESCE Working Papers", No. 59.

Molle W. (1997), The Regional Economic Structure of the European Union: an Analysis of Long-Term Developments [in:] Peschel K. (ed.), Regional Growth and Regional Policy Within the Framework of European Integration, Heidelberg: Physica-Verlag, http://dx.doi.org/10.1007/978-3-642-48428-5.

Perez C. (1983), Structural Change and Assimilation of New Technologies in the Economic and Social Systems, "Futures", Vol. 15, No 5, http://dx.doi.org/10. 1016/0016-3287(83)90050-2. 
Rosenstein-Rodan P.N. (1944), The International Development of Economically Backward Areas, "International Affairs", Vol. 20, No. 2, http://dx.doi.org/10. 2307/3018093.

Rostow W. (1959), The Stages of Economic Growth, "The Economic History Review", Vol. 12, No. 1, http://dx.doi.org/10.2307/2591077.

Rowthorn R., Ramaswamy R. (1997), Deindustrialization: Causes and Implications, "IMF Working Paper", WP/97/42.

Schettkat R., Yokarini L. (2006), The Shift to Services: A Review of the Literature, "Structural Change and Economic Dynamics", Vol. 17, Issue 2, http://dx.doi.org/ 10.1016/j.strueco.2005.04.002.

Schumpeter J. (2009), Kapitalizm, socjalizm, demokracja. Wydawnictwo Naukowe PWN, Warsaw, http://dx.doi.org/10.4324/9780203202050.

Stephan J. (2002), The Productivity Gap between East and West Europe: What Role for Sectoral Structures during Integration? "Acta Oeconomica”, Vol. 52, No. 3, http://dx.doi.org/10.1556/AOecon.52.2002.3.1. 